has thus inherited the uniform slope of hair which, I believe; is common to all mammals, but at some distant period of its evolution the abnormal horse began to assume the incipient variation because its ancestors were subject to friction from a collar sufficient to produce it, whereas the normal horse and its ancestors were not. We may surely to-day call these patterns " acquired characters," though their initial stages were too slight to be discovered. In such an inquiry as this, if we look away from the slight initial stages and concentrate attention only on fully formed "characters," we become bemused by this unfortunate term with all its implications. How does it help our view of the matter to call both the normal and abnormal slope "acquired" because the horse inherits the potentiality of responding thus to the stimuli of friction? If we must do so, we shall have to find some fresh term for the initial stages and changes of structure. Would Semon's conception embodied in the word "engram" not suit the case? On his hypothesis "engrams" are transmitted after the operation of a sufficient number of stimuli.

Will Sir Archdall Reid then tell us what he thinks of such initial variations as the one I have chosen, and what we should call them, if not "engrams"? These considerations are apart from the complications of inheritance introduced by bisexual reproduction and its shuffling effect on variations. WALTER KIDD.

2 Suffolk Square, Cheltenham, August 19.

\section{The "Radiant" Spectrum.}

The title refers to an interesting optical effect observed and described many years ago by Sir David Brewster (Phil. Mag., September, 1867), which appears, however, never to have been satisfactorily explained. When a small brilliant source of light is viewed through a prism held in front of the eye, a remarkable appearance is noticed, represented roughly in the accompanying diagram (Fig. I). In the continuation of the spectrum of the source, but considerably beyond its violet end, is seen a patch of light consisting of

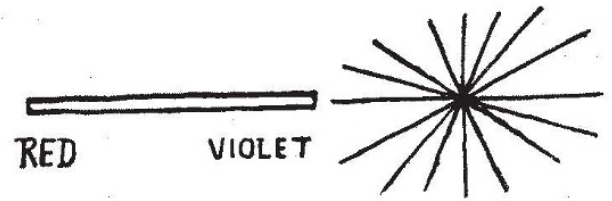

Fio. $x$.

streamers radiating from a centre, as shown. A brief statement on the cause of this effect, as determined in an investigation made by me, may be of interest to readers of NATURE.

The phenomenon is due to the diffraction of light in its passage through the eye by the corneal corpuscles. Were there no prior dispersion of the light by the prism, the diffraction-halo would appear to consist of streamers surrounding the source and radiating from it directly. The effect of the dispersion on the diffraction-halo is to shift its achromatic centre towards the side of the shorter wave-lengths-in fact, to a point lying considerably beyond the violet of the spectrum of the source, exactly as observed. The streamers in the halo really consist of elongated diffraction-spectra, and the effect of the prism is to reorient them, so that they now appear to diverge from the altered position of the achromatic centre. This explanation of Brewster's phenomenon is strikingly confirmed by the fact that very similar effects may be observed in the diffraction-halo due to a glass plate dusted with lycopodium, when held in front of the eye along with a $60^{\circ}$ glass prism.

22 Oxford Road, Putney, S.W.I5. C. V. Raman. August 12.

Remarkable July Rainfall at Blue Hill, Mass.

IN connection with the present abnormal season in North-Western Europe, it may be of interest to note that July, $x 9^{2} \mathrm{r}$, was not only the wettest July, but also the wettest month of any at Blue Hill since observations began thirty-six years ago. The co-ordinates of the observatory are $\phi=42^{\circ}{ }^{\prime} 2^{\prime} 44^{\prime \prime}$ N., and $\lambda=$ $71^{\circ} 6^{\prime} 53^{\prime \prime} \mathrm{W}$. Every effort has been made to preserve the integrity of the record. The total rainfall for July was $26 \mathrm{I} \mathrm{mm}$. (10443 in.), the normal rainfall for that month being $99 \mathrm{~mm}$. $(3.92 \mathrm{in}$.). There were eleven rainy days, and one on which a trace of rain fell.

So far as frequency is concerned, it was a normal month.

It is difficult to characterise properly the rainfall of a summer month, owing to variability in the intensity of thunder showers. During the past month there were no remarkably heavy downpours such as distort monthly totals. Also there was on the last day of June a heavy rainfall which, if allowed for, easily makes the period one of maximum rainfall. By comparison with long-period records at New Bedford, $68 \mathrm{~km}$. south (I07 years), and Boston, $16 \mathrm{~km}$. north (ro3 years), it is evident that the rainfall of July, I92 I, is the heaviest in a century. With the exception of August, 1826, when at New Bedford $475 \mathrm{~mm}$. was recorded, half of which, however, fell in 72 hours, the past month can be regarded as the wettest period in this section for more than a century.

Furthermore, this section of the North Atlantic coast is evidently in a period of maximum rainfall. At Blue Hill the data are as follows (in the upper row normal 35 -year-period rainfalls; in lower rows the departures for 1920 and 1921 ) :-

\begin{tabular}{|c|c|c|c|c|c|c|c|c|}
\hline $\begin{array}{l}35 \text { y } \\
1920 \\
1921\end{array}$ & $\begin{array}{r}\text { Jan. } \\
\mathrm{mm} . \text { Io3 } \\
-20 \\
-8\end{array}$ & $\begin{array}{r}\mathrm{Feb} . \\
\text { IOI } \\
+88 \\
-\quad \mathrm{I}\end{array}$ & $\begin{array}{l}\text { Mar. } \\
\text { I10 } \\
+25 \\
-38\end{array}$ & $\begin{array}{r}\text { Apr. } \\
94 \\
+69 \\
+36\end{array}$ & $\begin{array}{r}\text { May. } \\
9 \mathrm{I} \\
+\mathrm{IOI} \\
+\quad 4 \mathrm{I}\end{array}$ & $\begin{array}{r}\text { June. } \\
80 \\
+139 \\
+\quad 30\end{array}$ & $\begin{array}{r}\text { Julv, } \\
99 \\
-\quad 22 \\
+166\end{array}$ & \\
\hline & & + & $\begin{array}{ll}\text { 1g. Sept } \\
00 & \text { IO } \\
25 & -28 \\
- & -\end{array}$ & $\begin{array}{rr}\text { t. } & \text { Oc } \\
24 & 9 \\
28 & -4 \\
\end{array}$ & $\begin{array}{rr}2 . & \text { Nov } \\
99 & 96 \\
42 & +76 \\
\end{array}$ & 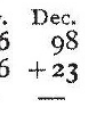 & $\begin{array}{l}\text { Year. } \\
1179 \\
\text { I621 } \\
-\end{array}$ & $\begin{array}{c}\text { Year/1 } 2 . \\
98 \\
135 \\
\text { I50 (?) }\end{array}$ \\
\hline
\end{tabular}

Alexander McAdie.

Harvard University, Blue Hill Observatory, Readville, Mass., August I.

\section{The "Philosophical Magazine."}

A LETTER which appears to have been widely circulated has reached me from the National Union of Scientific Workers virtually attacking the management of the Philosophical Magazine. Will you allow me, therefore, briefly to say that the referees mentioned on the title-page of that journal are frequently consulted, and that their services are not so nominal as the writers of the circular suppose?

I would add that, in my judgment, the Philosophical Magazine is well managed; that a conservative attitude towards old-established organs is wise; and that it is possible to over-organise things into lifelessness. Oliver Lodge. NO. 2705 , VOL. IO8] 